\title{
Sınıf Öğretmeni Adaylarının Hayat Bilgisi Dersindeki Sınıf İçi Öğretim Uygulamaları
}

\author{
Serdar YEȘİ ${ }^{1}$ ve Mecit ASLAN ${ }^{2}$
}

$\ddot{\mathrm{O} z}$

Bu çalışmanın amacı, öğretmen adaylarının öğretmenlik uygulaması kapsamında işledikleri Hayat Bilgisi dersinin sınıf içi öğretim uygulamalarını incelemektir. Çalışma, nitel araştırma desenlerinden durum çalışması desenine göre yürütülmüştür. Çalışmanın verileri, Van Yüzüncü Yıl Üniversitesi Eğitim Fakültesinde öğrenim gören ve öğretmenlik uygulamasına devam eden 11 sınıf öğretmeni adayından toplanmıştır. Çalışmada veri toplama aracı olarak, araştırmacılar tarafından geliştirilen gözlem formu ve yarı yapılandırılmış görüşme formu kullanılmıştır. Veriler, nitel veri analizi tekniklerinden içerik analizi ve betimsel analiz tekniklerinden yararlanılarak analiz edilmiştir. Çalışma sonucunda öğretmen adaylarının dersin giriş bölümünde en çok dikkat çekme uygulamalarına yer verdikleri, güdüleme uygulamalarına ise hiç yer vermedikleri, hedeften haberdar etme ve önkoşul öğrenmeleri hatırlatma amacına yönelik öğretim uygulamalarına çok az yer verdikleri sonucuna ulaşılmıştır. Öğretmen adaylarının dersin gelişme bölümünde daha çok düz anlatım ve soru cevap yöntemlerini kullandıkları, ağırlıklı olarak kullandıkları öğretim teknolojisinin/materyalinin etkileşimli tahta ve ders kitabı olduğu, süreçte ipucu ve dönütlere genel olarak yer verdikleri belirlenmiştir. Ayrıca, öğretmen adaylarının dersin sonuç bölümünde en çok yer verdiği uygulamanın değerlendirme, en az yer verdiği uygulamanın son özet olduğu tespit edilmiştir. Bu nedenle eğitim fakültelerinde öğretmen adaylarına dersin giriş, gelişme ve sonuç aşaması etkinlikleri hakkında uygulamalı eğitim verilmesi önerilebilir.

Anahtar Kelimeler: Sınıf Öğretmeni, Hayat Bilgisi, Öğretmenlik Uygulaması, Öğretim Etkinlikleri

\section{Preservice Class Teachers' In-Class Instruction Practıces in Life Science Course}

\begin{abstract}
The purpose of this study is to examine the in-class instruction practices of the preservice class student teachers in 'Life Science' course. The study was conducted in accordance with the case study model, which is one of the models of qualitative research. The data of the study were collected from 11 student teachers who are studying at Van Yüzüncü Yll University Faculty of Education and continue their teaching practices. An observation form and a semistructured interview form developed by the researchers were used as data collection tools. The data were analyzed by using content analysis and descriptive analysis techniques. In the study, it was concluded that the preservice teachers gave the most attention-taking practices in the introductory section of the course, they did not give any place to the motivation practices, and they gave very little place to the instructional applications for the purpose of informing the target and remembering the prerequisite learning. It was determined that the student teachers mainly use lecture and question-answer methods in the development section of the course. It has been determined that the most widely used instructional technology/material in life science course is interactive board and textbook. Additionally, it has been determined that student teachers give much place to evaluation but don't perform the last summarize in the final part of the course. For this reason, applied trainings on the introduction, development and final activities of the course should be given to preservice teachers.
\end{abstract}

Key Words: Preservice Class Teachers, Life Science, Teaching Practice, Teaching Activities

\section{Atıf İçin / Please Cite As:}

Yeşil, S. ve Aslan, M. (2020). Sınıf öğretmeni adaylarının hayat bilgisi dersindeki sınıf içi öğretim uygulamaları. Manas Sosyal Araștirmalar Dergisi, 9(2), 764-777.

Geliş Tarihi / Received Date: 15.05.2019

Kabul Tarihi / Accepted Date: 03.06.2019

\footnotetext{
1 Öğr. Gör. - Van Yüzüncü Y1l Üniversitesi Eğitim Fakültesi, syesil@yyu.edu.tr ORCID: 0000-0002-6307-175X

2 Dr. Öğr. Üyesi - Van Yüzüncü Yıl Üniversitesi Eğitim Fakültesi, maslan4773@gmail.com ORCID: 0000-0002-7970-5892
} 


\section{Giriş}

Bir ülkenin gelişip ilerlemesinde eğitim önemli bir yere sahiptir. Eğitimin planlı ve yaygın olarak verildiği yerler ise okullardır. Okullarında bu işlevini yerine getirmesinde en önemli rol öğretmenlere düşmektedir. Bu gerçekten yola çıkarak ülkeler öğretmen yetiştirme işine büyük önem vermektedir. Günümüzde öğretmenin niteliği ile eğitimin niteliği arasında sıkı bir ilişki olduğu görüşü yaygin bir şekilde kabul edilmektedir (Gürbüztürk ve Genç, 2004, s. 8). Nitekim alan yazında yapılan çalışmalar, başarıll bir eğitimin temel şartının öğretmenin niteliği olduğunu göstermektedir (Harris ve Sass, 2010, s. 807; Jacob ve Lefgren, 2004, s. 67).

Öğretmenlik mesleği bazı yeterliklere sahip olmayı gerektirmektedir. 1739 sayılı Milli Eğitim Temel Kanununa göre öğretmenlik mesleğine hazırlı̆̆ın; genel kültür, özel alan eğitimi ve pedagojik formasyon ile sağlanacağ1 ifade edilmektedir. Ayrıca son zamanlarda Milli Eğitim Bakanlığ1 öğretmenlik mesleğine ilișkin üç ana yeterlik alanı belirlemiștir. Bunlar; "mesleki bilgi”, "mesleki beceri”, "tutum ve değerler"dir. Bu yeterlik alanları içerisinde önemli bir yeterlik alanı "mesleki beceri”'dir. Mesleki beceri; "eğitim öğretimi planlama, öğrenme ortamları oluşturma, öğretme-öğrenme sürecini yönetme ve ölçmedeğerlendirme” alt yeterliklerini içermektedir (MEB, 2017). Öğretim uygulamalarının verimliliğinin önemli bir ön koşulu, öğretmenlerin öğretim uygulamaları konusunda gerekli yeterliklere sahip olmasıdır (Moore, 2000, s. 9). Öğretme-öğrenme süreci, öğrencilere dersin kazanımlarının öğretimine yönelik öğretim uygulamalarını kapsamaktadır. Öğretmenlerin öğrencilere istenilen nitelikleri kazandırmasında öğretim uygulamaları önemli bir işleve sahiptir. Öğretim uygulamalarının niteliği öğretmenin niteliğiyle doğrudan ilişkilidir. Bu nedenle mesleğe başlamadan önce öğretmen adayları, hem teorik hem de uygulamalı olarak nitelikli bir eğitimden geçirilmelidir.

Sınıf içi öğretim uygulamaları alan yazında üç ana bölümde ele alınmaktadır (Sönmez, 2010, s. 136; Taşdemir, 2000, s. 27; Yeşil ve Yeşil, 2007, s. 319): (a) Giriş etkinlikleri, (b) Gelişme etkinlikleri ve (c) Sonuç etkinlikleri. Giriş bölümünde dikkat çekme, güdüleme, hedeften haberdar etme, önkoşul öğrenmeleri hatırlatma uygulamaları yer almaktadır. Gelişme bölümünde giriş bölümüyle öğrenmeye hazır hale getirilen öğrencilere kazanımların öğretilmesine yönelik öğrenme öğrenme-öğretme etkinlikleri düzenlenmekte; ipucu, pekiştireç, etkin katılım ve dönüt-düzeltme uygulamalarına yer verilmektedir. Bu kapsamda öğretmenlerin özellikle çağdaş öğretim yöntem-tekniklerini kullanabilme ile ilgili yeterliklere sahip olması gerekmektedir (Demirel, 1999, s.81; Demirkan ve Saraçoğlu, 2016, s. 1). Ayrıca çağdaş eğitim anlayışında önemli öğretim uygulamalarından birisi de, öğretim materyallerinden sınıf içerisinde etkili olarak yararlanabilme becerisidir (Gagné, 1987, s. 3; Gagné, Briggs ve Wager, 1992). Dersin sonuç bölümünde ise özet, değerlendirme ve kapanış etkinlikleri düzenlenmektedir (Sönmez, 2010, s. 136). Öğretmenlerin sınıf içi öğretim uygulamalarını etkili bir şekilde uygulayabilmeleri nitelikli bir öğretmen eğitimi ile mümkündür.

Yıldırım’a (2013, s. 188) göre öğretmen eğitiminin nitelikli olup olmadığının esas göstergesi, öğretmenlik uygulamasına devam eden öğretmen adaylarının ya da öğretmen yetiştiren kurumlardan mezun olup mesleğe başlayan öğretmenlerin özellikle uygulama içerisindeki etkililiklerinin belirlenmesi ile ortaya konulabilir. Öğretmen yetiştirme programlarının etkililiğinin değerlendirilmesini tespit etmek amacıyla yapılan bazı çalışmalarda ise öğretmenlik uygulamalarının adaylara deneyim kazandırması bakımından faydalı olduğu belirlenmiştir. Buna rağmen öğretmenlik uygulamalanının yeterli olmadığı ve öğretmen adaylarının gelişimine tam anlamıyla katkı sağlayamadığı belirlenmiştir (Shantz, 2005, s. 192; Haydn ve Barton, 2007, s. 1021).

Öğretmen adaylarının fakültedeki eğitimlerinde aldıkları bilgileri pratiğe dökmelerinde, gerçek ortamda yaparak yaşayarak öğrenmelerinde fakültenin son sinıfında verilmekte olan Öğretmenlik Uygulamas1 dersi önemli bir yere sahiptir (Aslan, 2015; Baran, Yaşar ve Maskan, 2015, s. 232; Şişman ve Acat, 2003, s. 239). Öğretmen adaylarının yetiştirilmesinde önemli bir işlevi olan öğretmenlik uygulaması, fakültenin son sınıfındaki öğrencilerin ögretmenlik yolunda son provasıdır (Paker, 2008, s. 133). Öğretmenlik uygulaması aracılığıyla öğretmen adaylarından gerçek bir okul ortamında gözlem yaparak öğretme-öğrenme süreci hakkında deneyim kazanması sağlanır (Dursun ve Kuzu, 2008, s. 161). Sarıçoban (2008, s. 34) tarafindan yapılan araştırmada, okul deneyimi ve öğretmenlik uygulaması derslerinin öğretmen adaylarının eğitim sistemini daha iyi anlamalarını, öğretmen adaylarının eğitime daha geniş perspektiften bakabilmelerini sağladı̆̆ı sonucuna ulaşılmıştır. 
Öğretmenlik uygulamasının sunduğu en önemli firsatlardan biri öğretmen adaylarına sınıf içinde çeşitli uygulamalar yapma fırsatı sunmasıdır. Öğretmen adayları uygulama sürecinde çeşitli dersler işlemekte ve bu derslerde sınıf içi öğretim uygulamalarına ilişkin teorik bilgilerini uygulamaya geçirebilmektedirler. Bununla birlikte, öğretmenlik uygulamasının bu işlevinin ne düzeyde gerçekleştiği bir problem durumu olarak ifade edilebilir. Bu nedenle, öğretmen adaylarının ders işlerken hangi öğretim uygulamalarına, nasil ve neden yer verdiklerinin ortaya konulması gerekmektedir.

\section{Araştırmanın Amacı ve Önemi}

Bu çalışmanın amacı, öğretmen adaylarının öğretmenlik uygulaması kapsamında işledikleri Hayat Bilgisi dersinin sınıf içi öğretim uygulamalarını incelemektir. Çalışmanın bu genel amacı doğrultusunda aşağıdaki sorulara cevap aranmışır:

1. Öğretmen adayları hayat bilgisi dersinin giriş, gelişme ve sonuç bölümlerinde hangi öğretim uygulamalarına yer vermektedir?

2. Öğretmen adayları bu öğretim uygulamalarını nasıl kullanmaktadır?

3. Öğretmen adaylarının süreçte kullandıkları ve kullanmadıkları öğretim uygulamalarının nedenleri nelerdir?

Hayat bilgisi dersi ilkokulun ilk üç sınıfinda verilen derslerin belkemiğini oluşturmaktadır (Sabancı ve Şahin, 2005). Hayat bilgisi, ilkokulun ilk üç sınıfinda okutulan, öğrencinin birey olarak, toplum ve doğa hayatında karşılaştığı sorunların çözümüne katkı sağlayan, çocuğun kendi yaşantısını anlama ve anlamlandırmasına yardımcı olan, iyi bir insan olarak yetişmesi için temel bilgi, beceri ve olumlu kişisel nitelik ve değerleri kazandıran, öğrencinin derste aktif olmasını önemseyen, sosyal bilgiler, fen ve teknoloji derslerinin temelini oluşturan ve diğer derslerin merkezinde olan bir derstir (Aktepe ve Yalçınkaya, 2016, s. 145). Hayat bilgisi, çocuğun iyi bir insan, iyi bir vatandaş olması amacıyla, hayatı tanıyı hayata uyumunu kolaylaştıran, günlük yaşama dair konuları kaynaştırarak, geçmiş-bugün-gelecek bağlamında öğrenmelerini sağlayan, içeriğini doğa bilimleri ve sosyal bilimlerden seçerek bütüncül bir anlayışla sunan bir derstir (Aladağ, 2016, s. 4; Sağlam, 2015, s. 2). Hayat bilgisi dersinde, sosyal bilgiler, fen ve teknoloji, din kültürü ve ahlak bilgisi ve daha birçok disiplin içerisinde yer alan bilgi, beceri, değer (olumlu kişisel nitelik) konuları yaşamla ilişkilendirilerek ve somutlaştırılarak öğrencilere sunulmaya çalışılmaktadır (Aktepe ve Yalçınkaya, 2016, s. 145). Hayat bilgisi dersinin bu işlevlerini yerine getirebilmesi için öğretmenlerin sınıf içi öğretim uygulamaları konusunda gerekli yeterliklere sahip olması gerekmektedir. Öğretmenlerin bu yeterliklere sahip olması için hizmet öncesi öğretmen eğitimine gerekli önem verilmelidir. İlkokulda önemli bir işleve sahip olan Hayat Bilgisi dersindeki öğretim uygulamalarının belirlenmesinin öğretmen adaylarının hizmet öncesi eğitim faaliyetlerine katkı sağlayacağı düşünülmektedir. Ayrıca, öğretmen adaylarının çeşitli derslerdeki sınıf içi öğretim uygulamalarının ele alındığı çalışmaların eksikliği düşünüldügünde, bu çalısmanın ilgili alanyazına katkıda bulunacağı da söylenebilir.

\section{Yöntem}

Bu çalışma nitel araştırma yöntemi temel alınarak yürütülmüsstür. Nitel çalışmalarda araştırmacı, katılımcılarla doğrudan görüşmeler yapan, gerekli olduğunda onların yaşantılarını deneyimleyen ve bu alanda elde ettiği deneyimlerden toplanan verileri analiz etmede yararlanan kişidir. Ayrıca nitel araştırmanın bir başka özelliği de, genellemeye ulaşmayı temel amaç edinmemesidir (Yıldırım ve Şimşek, 2013, s. 39).

\section{Araştırma Deseni}

$\mathrm{Bu}$ araştırma, nitel araştırma desenlerinden durum çalışması desenine uygun olarak yapılmıştır. Yıldırım ve Şimşek'e (2013, s. 83) göre durum çalışması, araştırmacının kontrol edemediği bir olgu ya da durumu, niçin ve nasıl sorularını esas alarak derinlemesine incelemeye imkân veren araştırma desenidir. Creswell'e (2007, s. 73) göre durum çalışması; araştırmacının sınırlandırılmış bir veya birkaç durumu, zaman içerisinde görüşmeler, gözlemler, dokümanlar, raporlar, görsel-işitseller gibi çoklu kaynakları içeren veri toplama araçları ile derinlemesine inceleyerek duruma bağlı temaların tanımlandığı nitel bir araştırma yaklaşımıdır. Bir başka ifadeyle durum çalışması, sınırlı bir olgu ya da durumun derinlemesine betimlenip incelenmesidir (Merriam, 2013). Bu çalışmada öğretmenlik uygulamasına devam eden öğretmen adaylarının Hayat Bilgisi dersindeki sınıf içi öğretim uygulamaları belirlenmeye çalışıldığından bu desene uygun olduğu söylenebilir. 


\section{Çalışma Grubu}

Araştırma, amaçlı örnekleme yöntemlerinden benzeşik örnekleme yöntemiyle seçilmiş 11 sinıf öğretmeni adayından oluşmaktadır. Amaçlı örnekleme, araştırmacının öznel amaçlarına uygun olarak evrenden seçim yapmak suretiyle örneklemi tespitidir (Balc1, 2005, s. 90). Benzeşik örnekleme yöntemi ise, evrenden araştırmanın problemine uygun olarak homojen bir alt grubun ya da durumun seçilmesi ve çalışmanın bu örneklem üzerinde ayrıntılı olarak yapılmasını hedefler (Büyüköztürk ve diğerleri, 2010, s. 91; Neuman, 2014). Çalışma grubunda yer alan öğretmen adaylarının 6'sı erkek, 5’i ise kadındır.

\section{Verilerin Toplanmas1}

Araştırmanın verileri, çalışma grubu olarak belirlenen 11 sınıf öğretmeni adayının öğretmenlik uygulaması kapsamında gözlenmesi ve söz konusu öğretmen adaylarılyla yapılan görüşmeler yoluyla toplanmiştır.

GöZlem. Gözlem herhangi bir yerde ortaya çıkan davranışı kapsamlı, ayrıntılı ve zamana yayılmış olarak tanımlamak amacıyla yararlanılan bir yöntemdir (Bailey, 1982; Yıldırım ve Şimşek, 2013, s. 89). Araştırmada öğretmen adaylarının gerçekleştirdikleri öğretim uygulamalarını ve bu uygulamaları nasıl gerçekleştirdiklerini belirlemek için gözlemler yapılmıştır. Gözlemler öğretmenlik uygulaması sırasında 12 hafta boyunca sürmüştür. Söz konusu gözlemlerde araştırmacılar tarafından hazırlanan gözlem formu kullanılarak araştırmanın amaçları çerçevesinde veri oluşturacak notlar alınmıştır. Gözlemler klasik sıralı düzenle oturulan, öğretmen masası ve dolabı ile etkileșimli tahtanın yan yana bulunduğu dersliklerde, arka sıraya tüm sınıfin görülebileceği bir yere oturularak gerçekleştirilmiştir. Sınıf içinde yapılan gözlemler bulgular bölümünde gözlem sırasına göre G1, G2, G3, ... şeklinde kodlanmıştır.

Görüssme. Çalışma grubundaki öğretmen adaylarıyla bireysel görüşme yapılmış, yarı yapılandırılmış görüşme tekniği kullanılmıştır. Glesne’ye (2014, s. 141) göre yarı yapılandırılmış görüşme tekniği, araştırmacının, araştırmaya önceden belirlediği bazı görüşme soruları ile başlayıp araştırma süresince onları yeniden biçimlendirerek yeni sorular ekleyebildikleri bir tekniktir. Katılımcilardan izin alınarak görüşme sırasında ses kayıt cihazıyla kayıt tutulmuş, daha sonra tutulan kayıtların çözümlemesi yapılmıştır. Öğretmen adaylarıyla yapılan görüşmeler bulgular bölümünde her öğretmen adayına bir numara verilerek Ö1, Ö2, Ö3, ... şeklinde kodlanmıştır.

\section{Verilerin Analizi}

Araştırma sürecinde gözlem ve görüşme yoluyla toplanan veriler, nitel veri analizi tekniklerinden içerik analizi ve betimsel analiz tekniklerinden yararlanılarak analiz edilmiştir. Öğretmen adaylarının hangi sınıf içi öğretim uygulamalarını yaptıklarını belirlemek için içerik analizi, bu analizleri nasıl ve niçin yaptıklarını belirlemek için ise betimsel analiz kullanılmıştır. İçerik analizinde detaylı bir çalışma ile kavramlar ve temalar belirlenirken; betimsel analizde verilerin önceden belirlenmiş temalar doğrultusunda özetlenip yorumlanması söz konusudur (Yıldırım ve Şimşek, 2013, s. 224). Bu çerçevede gözlem ve görüşmeler sonunda elde edilen veriler kodlanmış ve bu kodlar bazı temalar altında toplanmıştır. Analizde ulaşılan kodların üç ana temada (giriş bölümü uygulamaları, gelişme bölümü uygulamaları ve sonuç bölümü uygulamaları) toplandığına karar verilmiştir. Yapılan temalandırma sonunda ortaya çıan bulgular tablolar şeklinde özetlenmiş; yorumlanmış ve alan yazın eşliğinde tartışılmıştır.

\section{Geçerlik ve Güvenirlik}

Araştırmanın geçerliğini sağlamak için, araştırmacı gözlemi döneme yaymış, kendisi de gözlemci olarak çalısmaya katılmıştır. Ayrıca araştırılan konu hakkında deneyimli olan üçüncü bir meslektaş tarafindan analizler tutarlık incelemesine tabi tutulmuş ve oluşturulan temaların içeriğe uygunluğu teyit edilmiştir. Ayrıca elde edilen sonuçlar hakkında katılımcı teyidi alınarak araştırmanın iç geçerliliği artırılmaya çalışılmıştır.

Verilerin analizi sürecinde yapılan kodlamaların araştırmacının bireysel etkisinden arındırılması önem taşımaktadır. Bireysel etkinin olumsuzluğunu/yanlılı̆̆1 ortadan kaldırabilmek için farklı kodlayıcıların kullanılması ve görüşler arasında benzerliğin belirlenmesi önerilmektedir (Baltac1, 2017, s. 4; Türnüklü, 2000, s. 551). Baltac1 (2017, s. 4) ve Türnüklü (2000, s. 551), kodlayıc1lar arasında tutarliliğın belirlenebilmesi; başka bir ifade ile objektifliğin ve böylelikle güvenirliğin sağlanabilmesi için Miles ve Huberman (1994) formülünün (Güvenirlik= Görüş Birliği/Görüş Birliği + Görüş Ayrllı̆ı) kullanılmasını önermektedirler. Çalışma verileri iki araştırmacı tarafından bağımsız olarak kodlanmış ve kodlayıcılar 
arasındaki uyum hesaplanmıştır. Yapılan hesaplama neticesinde uyum oranı \% 91 olarak tespit edilmiştir. Ulaşılan bu değerin \%70’in üzerinde olması ulaşılan bulguların ve sonuçların güvenilir olduğunu göstermektedir.

\section{Bulgular}

Öğretmen adaylarının öğretmenlik uygulaması kapsamında işledikleri Hayat Bilgisi dersinin sınıf içi öğretim uygulamalarının ele alındığı bu çalışmada elde edilen bulgular araştırma soruları doğrultusunda aşağıda sunulmuştur.

\section{Öğretmen adayları hayat bilgisi dersinin giriş, gelişme ve sonuç bölümlerinde hangi öğretim uygulamalarına yer vermektedir?}

Öğretmen adaylarının hayat bilgisi dersinin giriş, gelişme ve sonuç bölümlerindeki sınıf içi öğretim uygulamalarına ilişkin bulgular Tablo 1'de verilmiştir.

Tablo 1. Hayat Bilgisi Dersinin Giriş Bölümünde Kullanılan Simnf İ̧̨i Öğretim Uygulamalar

\begin{tabular}{lll}
\hline Tema & \multicolumn{1}{c}{ Alt Tema } & $f$ \\
\hline \multirow{2}{*}{ Girişs } & Dikkat çekme & 7 \\
& Güdüleme & - \\
& Hedeften haberdar etme & 2 \\
& Ön bilgileri hatırlatma & 2 \\
\hline
\end{tabular}

Tablo 1'de görüldüğü gibi öğretmen adaylanı işledikleri derslerin giriş bölümünde dikkat çekme $(\mathrm{f}=7)$, hedeften haberdar etme $(\mathrm{f}=2)$ ve ön bilgileri hatırlatma $(\mathrm{f}=2)$ uygulamalarına yer vermişlerdir. Yapılan gözlemlerde öğretmen adaylarının öğrencileri güdüleme amacıyla herhangi bir öğretim uygulamasına yer vermedikleri belirlenmiştir. Buna göre en çok gözlenen giriş uygulaması dikkat çekme, hiç gözlenmeyen uygulama ise güdülemedir.

Tablo 2. Hayat Bilgisi Dersinin Gelişme Bölümünde Kullanılan Sımf İçi Ögrretim Uygulamalar

\begin{tabular}{|c|c|c|c|}
\hline Tema & Alt Tema & Kod & $f$ \\
\hline \multirow{13}{*}{ Gelişme } & \multirow{4}{*}{ Yöntem ve Teknik Kullanımı } & Soru cevap & 12 \\
\hline & & Anlatım & 6 \\
\hline & & Rol oynama & 3 \\
\hline & & Drama & 2 \\
\hline & \multirow{4}{*}{$\begin{array}{l}\text { Öğretim Teknolojileri ve Materyal } \\
\text { Kullanımı }\end{array}$} & Etkileşimli tahta & 6 \\
\hline & & Ders kitab1 & 4 \\
\hline & & Tasarlanmış materyaller & 1 \\
\hline & & Beyaz yazı tahtas1 & - \\
\hline & \multirow{5}{*}{ Eğitim Durumları Değişkenleri } & İpucu & 12 \\
\hline & & Dönüt & 12 \\
\hline & & Etkin katılım & 12 \\
\hline & & Pekiştireç & 10 \\
\hline & & Düzeltme & 8 \\
\hline
\end{tabular}

Tablo 2'de görüldüğü gibi, dersin gelişme bölümünde soru cevap ( $\mathrm{f}=12$ ), anlatım ( $\mathrm{f}=6$ ), rol oynama $(\mathrm{f}=3)$, drama $(\mathrm{f}=2)$ yöntemlerine yer verilmiştir. Buna göre en çok gözlenen yöntemin soru cevap, en az gözlenen yöntemin drama olduğu belirlenmiştir. Öğretmen adaylarının Hayat Bilgisi dersini işlerken tabloda verilenlerin dışında herhangi bir yöntem ve teknik kullanmadıkları gözlenmiştir.

Gözlem sırasında öğretmen adaylarının kullandıkları öğretim teknolojileri ve materyallerin neler olduğu da belirlenmeye çalışılmıştır. Bu çerçevede yapılan gözlemlerde öğretmen adaylarının dersin gelişme bölümünde etkileşimli tahta $(\mathrm{f}=6)$, ders kitabı $(\mathrm{f}=4)$, tasarlanmış materyal $(\mathrm{f}=1)$ kullandıkları belirlenmiştir. Buna göre en çok kullanılan materyalin etkileşimli tahta, en az kullanılanın ise tasarlanmış materyaller olduğu tespit edilmiştir. Ayrıca yapılan gözlemlerde, öğretmen adaylarının beyaz yazı tahtasını kullanmadıkları belirlenmiştir.

Tablo 2'de görüldüğü üzere, öğretmen adaylarının dersin gelişme bölümünde eğitim durumu değişkenlerine başvurdukları, bu değişkenlerden etkin katılım $(\mathrm{f}=12)$, dönüt $(\mathrm{f}=12)$, ipucu $(\mathrm{f}=12)$, pekiştireç $(\mathrm{f}=10)$ ve düzeltmeyi $(\mathrm{f}=8)$ sıklıkla kullandıkları gözlenmiştir. Bu bulgudan hareketle en çok kullanılan eğitim durumu değişkeninin etkin katılım, dönüt ve ipucu; en az gözlenen eğitim durumu değişkeninin ise düzeltme olduğu söylenebilir. 
Tablo 3. Hayat Bilgisi Dersinin Sonuç Bölümünde Kullanılan Simı İ̧̧i Öğretim Uygulamaları

\begin{tabular}{cll}
\hline Tema & Alt Tema & $f$ \\
\hline \multirow{2}{*}{ Sonuç } & Özetleme & 1 \\
& Değerlendirme & 6 \\
& Kapanış & 2 \\
\hline
\end{tabular}

Tablo 3 incelendiğinde, öğretmen adaylarının işledikleri Hayat Bilgisi derslerinin sonuç bölümünde özetleme $(\mathrm{f}=1)$, değerlendirme $(\mathrm{f}=6)$ ve kapanış $(\mathrm{f}=2)$ uygulamalarına yer verdikleri görülmektedir. $\mathrm{Bu}$ bulgular dersin sonuç bölümünde en çok yer verilen öğretim uygulamasının değerlendirme, en az yer verilen öğretim uygulamasının ise özetleme olduğunu göstermektedir.

\section{Öğretmen Adayları Hayat Bilgisi Dersinde Öğretim Uygulamalarını Nasıl Kullanmaktadır?}

$\mathrm{Bu}$ araștırma sorusuna yanıt verebilmek için bir önceki araştırma sorusunda elde edilen ve tablolar halinde sunulan öğretim uygulamalarının nasıl yapıldığına odaklanılmıştır. Öğretmen adaylarının dersin giriş bölümünde en çok yer verdikleri uygulamanın dikkat çekme olduğu belirlenmiştir (Bkz. Tablo 1). Dersin giriş bölümünde dikkat çekme aşamasında öğretmen adaylarının farklı uygulamalara yer verdikleri tespit edilmiştir. Öğretmen adaylarının dikkat çekme aşamasında ağırlıklı olarak soru kullandıkları belirlenmiştir. Örneğin; dersin başında Ö3 "Dün kim çantasım hą̌rladı?”, Ö4 "Evimizdeki kaynaklar nasıl kullanacă̆ız?", Ö6 "Hepimiz̨in bir ailesi var mı?” sorularını sormuşlardır. Ayrıca, bazı öğretmen adaylarının da başlarından geçen bir olay kullandığı gözlenmiştir. Örneğin Ö3 ve Ö5, dersin başında dikkat çekme amacıyla başından geçen bir anısını anlatmıştır. Aşağı̆da öğretmen adaylarının dikkat çekmede başlarından geçen bir olayı nasıl kullandıkları ile ilgili gözlem notlarına yer verilmiştir:

Ö5, gesen haftaki konuyu haturlatarak "engellilere yardm etmemiz. gerekiyor demiştik ya" dedi ve "okula gelirken engelli bir amca karş̧ya geçmeye çalssıyordu, onun koluna girerek karșiya geçmesine yardimc oldum" dedi ve ardindan ögrencilere soru sordu. "Kimlere yardm ederiz??" (G8)

Dersin giriş bölümü uygulaması olan hedeften haberdar etme, yalnızca iki kez aynı öğretmen adayı tarafindan kullanılmıştır. Söz konusu öğretmen adayı (Ö2) işlediği derslerin birinin giriş bölümünde "bugün

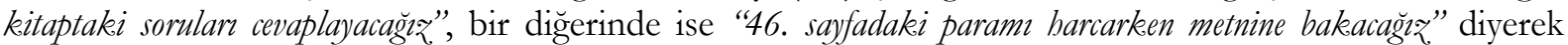
öğrencileri hedeften haberdar etmiştir. Dersin giriş bölümünde ön bilgileri hatırlatma uygulaması sadece iki kez gözlenmiştir. Ö4 "gesen hafta hayat bilgisi dersinde ne işledik?" şeklinde soru sorarak öğrencilerin önceki hafta öğrenilen bilgileri hatırlamalarını sağlamıştır. Ö5 ise dersin başında geçen dersteki konuyu hatırlatarak "Geçen haftaki derste engellilere nasıl davranacağımızı açılamıştık. Engellilere yardım etmemiz gerekiyor demişstik" (G8) diyerek önceki derste öğrenilenleri kendisi açıklamak suretiyle önkoşul öğrenmelerin hatırlanmasını sağlamıştır.

Dersin gelişme bölümünde öğretmen adaylarının en sık kullandığı yöntem ya da tekniğin soru cevap olduğu gözlenmiştir (Bkz. Tablo 2). Öğretmen adaylarının soru cevap tekniğini kullanırken, öğrencilerden söz hakkı almalarını istedikleri, genellikle parmak kaldıranlara söz hakkı verdikleri, öğrencilere isimleriyle hitap ettikleri, öğrencilerin cevaplarına ek açıklamalarla destek verdikleri tespit edilmiştir. Ayrıca öğretmen adaylarının soru cevap tekniğini genellikle ders kitabındaki ve etkileşimli tahtadaki soruları cevaplamada kullandığ1 tespit edilmişsir. Aşağıda öğretmen adaylarının soru-cevap tekniğini nasıl kullandıkları ile ilgili gözlem notlarına yer verilmiştir:

Ö4 "biz. bayramda kimleri ziyaret ediyoruz?" sorusunu sorduktan sonra ögrencilerden parmak kaldrmalarm isteyip ismini söyleyerek ögrenciye söz, hakek verdi. Verilen cevaptan sonra ögrretmen adayz "mesela dedelerimizzin,

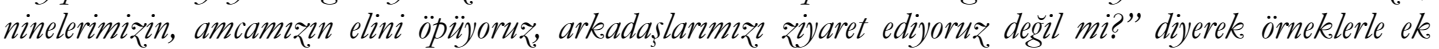
açklamalar yapt.. (G6)

Ö6 "Bir videomu₹ var, herkes dikekatli dinlesin, soru soracağrm" dedi. Etkilesimli tabtadan videoyu iə̌letip durdurdu ve "buna hangi tür aile diyorų?" diye sordu ve ögrenciler hep birden "çekirdek" dedi. Sonra videoyu izletmeye devam etti ve tekrar durdurup soru sordu. (G7)

Öğretmen adaylarının iki kez drama ve üç kez rol oynama tekniğini kullandığı tespit edilmiştir. Bir öğretmen adayı "istek ve ihtiyaçlarımız" konusu işlenirken drama yöntemini kullanmıştır. Aynı öğretmen adayı cumhuriyet konusunun işlendiği derste drama yapılacağını söylemiş; ancak yaptığı uygulamanın drama değil rol oynama olduğu belirlenmiştir. Aşağıda öğretmen adaylarının drama yöntemini nasıl kullandıkları ile ilgili gözlem notlarına yer verilmiştir: 
Ö5 "Küç̈̈k bir oyun oynayalm, bir drama yapalım" dedi, ögrencilerden dört kişi seçti. Öğretmen masasmı kenara çekti, tabtanm önünü boşalttı. Öğrencilere ne yapacaklarm açıkladı. Öğrenciler canlandırma yaparken ögretmen aday da bažen müdahale ederek ne yapacaklarn hakkenda uyarda bulundu. Ögrenciler olayn canlandirdıktan sonra Ö5 de "bu durumda nasil karar vereceksiniz??" seklinde soru sorup ögrrencilerin düssüncelerini almuștır. (G8)

Ö5, bir ̈̈ğrencinin padişah rolüne girmesini istedi, hažrladiğ tac ve pelerini bu ögrencinin takmasin sağladı.

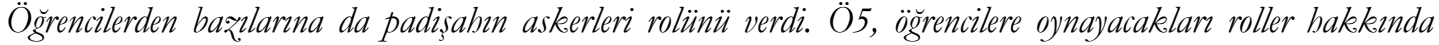
açıllama yaptı, yönergeler vererek ögrencilerin rol yapmalarm sağladı. Ardindan ögrencilere etkinlikle ilgili soru sordu. Ö5 daha sonra da günümïzdeki cumburbaşkanluğ seçimini canlandrmalarm sağladı. Ö5 ögrencilerin ber iki durumu karşılastırmalarmı istedi. (G1)

Öğretmen adaylarının anlatım yöntemini etkinliklerden sonra özet yapmada kullandığı ve kısa tuttuğu dikkati çekmektedir. Örneğin; Ö2 sorduğu soruda geçen "kombi" kavramının, bir başka soruda ise "gelirgider" kavramının anlamını anlatım yöntemiyle açıklamıştır. Yine Ö4 ise etkileşimli tahta aracilığıyla konunun anlatıldığ1 videoyu izlettikten sonra anlatım yöntemiyle konuyu özetlemiştir. Yine Ö6, öğrencilerden aile bireylerini söylemelerini istedikten sonra, öğrenci aile bireylerini saymış, Ö6 "anne, baba ve çocuktan oluşan ailelere çekirdek aile diyoruz" ş̧eklinde anlatım yöntemini kullanmışır.

Öğretmen adaylarının derste en çok kullandığı öğretim teknolojisi ve materyalinin etkileşimli tahta olduğu tespit edilmiștir. Öğretmen adaylarının etkileșimli tahta aracıllğıyla daha çok "morpa kampus" web sitesinden etkinlik yaptırdıkları, soruları cevapladıkları, bunun yanı sıra şarkı dinleme ve video izlemede kullandıkları belirlenmiştir. Aşağıda öğretmen adaylarının etkileşimli tahtayı nasıl kullandıkları ile ilgili gözlem notlarına yer verilmiştir:

Ö4, etkilesimli tabtadan "morpakampüs" web sitesinden bir ders videosu açt, dikkatli dinlemelerini, soru soracağmm söyledi. Videoyu iə̨lerken bir süre sonra durdurup "Annesi niçin sinirlenmis??" diye sordu. Cocuklardan biri "sular kesilmis diye" dedi. Video iəlemeye devam ettiler, tekrar videoyu durdurdu ve "Babaannenin mutlu olmasinn sebebi ne?" diye sordu. Parmak kaldrmalarm istedi, ögrenciye ismiyle hitap ederek söz, hakke verdi. Ögrenci cevapladv ve Ö4 "aferin" dedi. Ö4 tekrar videoyn oynattı ve... (G9)

Öğretmen adaylarının ipucu olarak örnek verme, açılama yapma, soru sorma yoluna başvurdukları tespit edilmiştir. Örneğin Ö2, öğrenci kitaptaki soruyu okuduktan sonra, "soruyu anladınız mı?" diye sınıfa sormuş, Öğretmen adaylarının ipucunu soru cevap yönteminde cevap gelmediğinde ya da yanlış cevap geldiğinde düzeltme amacıyla kullandıkları tespit edilmiştir. Aşağıda öğretmen adaylarının ipucunu nasıl kullandıkları ile ilgili gözlem notlarına yer verilmiştir:

Ö2 "3. soruyu kim okuyacak" dedi ve parmak kaldiran bir ögrenciye söz hakker verdi. Soruyu ögrenci okuduktan sonra Ö2, "Soruyu anladmı m??" diye sordu ve soruyu tekrarladı. "Evimizde hangi kaynaklar var?" diye sordu. Ö2 cevap gelmeyince evdeki kaynaklar sayd ve "bunlar kullanirken nelere dikkat etmeliyiz?" sorusunu okuyup cevabı kitaba yazmalarm istedi. Bu arada örnek vererek, açklama yaparak. ögrencilere ipucu verdi. (G10)

Hayat Bilgisi dersinde öğretmen adaylarının dersin sonuç bölümünde en az yer verdiği uygulamanın son özet ( $\mathrm{f}=1$ ) olduğu belirlenmiştir (Bkz. Tablo 3). Burada öğretmen adayının dersin özetini öğrenciye yaptırdığı, bu amaçla öğrencilere soru yönelttiği görülmüştür. Hayat Bilgisi dersinde öğretmen adaylarının dersin sonuç bölümünde en çok kullandığı uygulamanın değerlendirme ( $\mathrm{f}=6)$, daha sonra ise kapanış ( $\mathrm{f}=2$ ) olduğu tespit edilmiştir (Bkz. Tablo 3). Aşağıda öğretmen adaylarının özetlemeyi nasıl yaptıkları ile ilgili gözlem notlarına yer verilmiştir:

Ö3 "Bugün neler ̈̈̈rrendik?” diye sordu ve ögrencilere ismiyle bitap ederek söz, hakke verdi, doğru söyleyenlere "aferin sana" dedi, bazılarmm cevaplarm da "değil mi" diye onaylad." Gün içinde başka neler yapmamız. gerekiyordu?" diye sordu. Ögrenciler cevap verdi, Ö3 "evet değil mi” diye onaylad. (G12)

Ö4 etkileşimli tabtadaki etkinlikleri bitirdikten sonra "derste neler ögrrendik soru soracağrm" dedi ve "Evimizdeki kaynaklar nelerdi?" diye sordu, parmak. kaldrmalarm istedi ve isimleriyle söz, bakke verdi. "Lamba" diyen ögrenciye "elektrik" dedi. Doğru cevaplayanlara "aferin" dedi. Ö4 "Şimdi deve-cüce oynayacağž" dedi ve oyun oynattı. Zil çald ve dışar çıktılar. (G9) 


\section{Öğretmen adaylarının süreçte kullandıkları ve kullanmadıkları öğretim uygulamalarının nedenleri nelerdir?}

Öğretmen adaylarının dersin giriş bölümünde güdüleme ve hedeften haberdar etme uygulamalarına pek yer vermedikleri belirlenmiştir. Öğretmen adayları bu durumun, güdüleme ve hedeften haberdar etmenin nasıl yapıldığını bilmediklerinden, zaman yetersizliğinden, teori ile uygulamanın birbirinden farklı olduğunu, dikkat çekme aşamasında anlatılan hikâye ya da olayın hedeften haberdar etme ve güdülemeyi sağladığını, hedefi süreçte öğrencilerinin kendilerinin bulmasının daha faydalı olduğunu düşünmelerinden kaynaklandığını ifade etmişlerdir. Aşağıda öğretmen adaylarının güdüleme ve hedeften haberdar etme uygulamalarına neden yer vermedikleri ile ilgili görüşme notlarına yer verilmiştir:

"Girişste bedeften haberdar etmiyoruz, ögrencinin hedefi ders süreci içerisinde kendisinin bulmasm istiyoru: Güdülemenin ne olduğunu bilmiyoru₹. Hikâye anlattrğımı̨da çocuğu bir nevi güdülemis de oluyoru₹:" (Ö3)

"Dersin başinda örnek bir olayla isleyeceğimiz. konuyu ögrrenciye kesfettiriyorum. Doğrudan ş̧ konuyu işleyeceğż' demek yerine, örnek olaydan bareketle ögrenciye konuyu buldurmann daha etkili olacağina inanyorum. Ne işe yarayacağzn ben söylemiyorum, ögrencilerin sürecte kendilerinin kesfetmesinin daha faydalı olacağın düsünüyorum." (Ö5)

"Hayat bilgisi bir saat işliyordum. Bu nedenle güdüleme yapmuyordum. Zaman yetersizliğinden oluyor. Cocuklar bugünkü dersimiz hayat bilgisi diyerek, hedeften haberdar ettim. Bazen çocuklar bugünkü dersimizde şu konuyu ögreneceğiz dedim." (Ö4)

Öğretmen adaylarının dersin gelişme bölümünde daha çok düz anlatım, soru cevap yöntemlerini kullandıkları, az miktarda drama ve rol oynama yöntemlerine yer verdikleri belirlenmiştir. Öğretmen adaylarının düz anlatım ve soru cevap ağırlıklı ders yapmalarının, diğer yöntem ve tekniklere başvurmamalarının, düz anlatım ve soru cevap yöntemlerinin daha kolay olması, sınıf mevcutlarının fazla olması, zamanın yetersiz olması, anlatım yöntemiyle yetişmiş olmaları, yöntem bilgisi konusundaki eksiklikleri, stajyer öğretmen olmaları nedeniyle sınıf yönetimi konusunda sorun yaşamalarından kaynaklandığını ifade etmişlerdir. Aşağıda öğretmen adaylarının ağılıklı olarak düz anlatım ve soru cevap yöntemlerine neden yer verdikleri, diğer yöntemlere neden yer vermedikleri ile ilgili görüşme notlarına yer verilmiştir:

"Diger yöntem ve teknikleri kullanamamamm nedeni, ilkokul birinci sinflara girmem ve ögrencilerin okuma yaz̧ma bilmemeleri, dersi görsellerle vermemiz gerekiyor. Okuma yazma bilmedikleri için daha çok sözel iletişim üzerinden gitmem gerekiyordu" (Ö3)

"Sorumluluklarmm fazla, elli bir zaman sorunu yassyorum. Okul dersleri, KPSS kaygisl, okuldaki sinavlardan dolayı kolaya kaçıyorum. Düz anlatım ve soru cevap yöntemini kullanmı kolay olduğundan ve çok

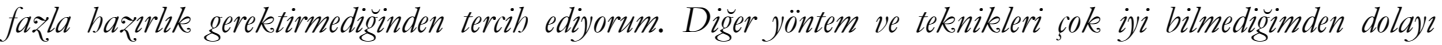
kullanmyyorum. Cünkë fakültede sadece okuyarak ya da hocadan dinleyerek iyi bu konular ögrenemeyebiliyoru:" (Ö5)

"Simf mevcutlarmin fą̧la, stajyer ögretmen olduğum için simf yönetimi konusunda sorun yaşzyorum, yeterince

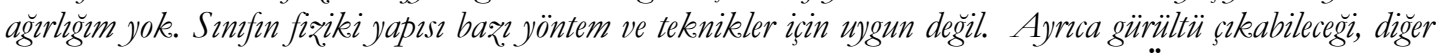
sinflarm rahatsız, olabileceği düsüncesiyle fark l yöntem ve teknikleri kullanamiyorum.”(Ö2)

"Daba çok anlatum yöntemi, soru cevap, örnek olay yöntemlerini kullandem. Anlatmm özellikle konuyu sunarken kullandim. Stajda diğer yöntemleri kullanamadim. Bu konuda kendimi yetersiz, hissediyorum. Bilgi

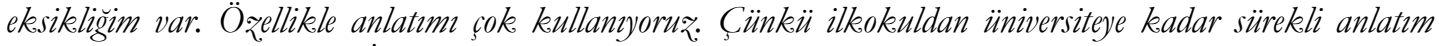
yöntemiyle karşzlassyoruz: İster istemez ben de anlatm yöntemini kullanyorum. Farkh bir șey yapmak istiyorsun ama yapamiyorsun. Çünkü hep anlatıma dayal eğitim sistemiyle yetiștirildik.” (Ö4)

Öğretmen adaylarının ipucu, pekiştireç, katılım ve dönüt-düzeltme uygulamalarına genel olarak yer verdikleri gözlenmişti. Yapılan görüşmelerde pekiştirecin öğrencilerin öğrenme ilgi ve isteğini artırmanın yanı sıra, etkin katılımı teşvik ettiği için öğretmen adayları tarafindan kullanıldığı belirlenmiştir. Ayrıca öğretmen adaylarının, öğrencilere öğrendiklerinin doğru olup olmadığı hakkında bilgi vermek için dönütdüzeltme uygulamalarına yer verdikleri belirlenmiştir. Yine öğretmen adayları özellikle öğrencilere sorulan sorularda soruyu anlamadıklarında ya da cevabı bulmakta zorlandıkları durumlarda farklı yollarla ipucu kullandıkları belirlenmiştir. Aşağıda öğretmen adaylarının ipucu, pekiştireç ve dönüt-düzeltme uygulamalarına yer verme nedenleri ile ilgili görüşme notlarına yer verilmiştir: 


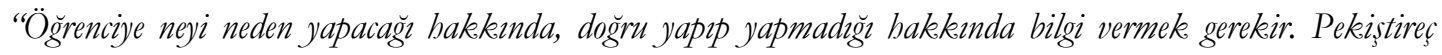
vermek ögrencinin ögrenme isteğini artiryor. Dönüt verilmezse belirsiallik durumu olusmakta, bu da bassaryz düsürmektedir. Özellikle soru cevap etkinliklerinde ipucu verilmektedir."(Ö7)

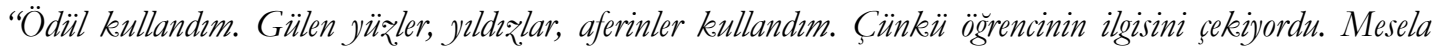

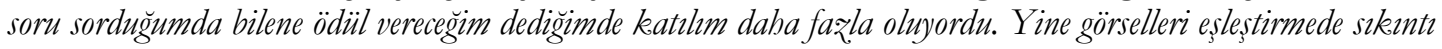
çekiyorlard. 'Bunu biç görmediniz, mi, kullanmadin mı?' diye soruyordum. Mesela peyniri gördü̈̈̈̈nde 'böreğ̈n içinde kullanilyyor' diye açılama yaparak ipucu veriyordum. Dönüt-düzeltme sık sı kullanmak zorunda kalyyordum. Öğrenciler 'ögretmenim doğru yaptım m??' diye soruyorlard, onlara dönüt düzeltme sağhyordum."

(Ö8)

Öğretmen adaylarının öğretim teknolojilerinden/materyallerinden özellikle etkileşimli tahtay1 kullandıkları tespit edilmiştir. Öğretmen adaylarının etkileşimli tahtayı kullanma ve diğer materyalleri kullanmama nedenleri arasında; etkileşimli tahtanın görsel olarak çok zengin olması, öğrenme ortamını zenginleştirmesi, öğrencinin dikkatini çekmesi, çocuklar tarafından rahatlıkla görülebilmesini ifade etmişlerdir. Diğer materyalleri çok fazla tercih etmeme nedenleri arasında ise etkileşimli tahtanın materyal yönüyle yeterli ve zengin olduğunu, diğer materyallere ulaşamadıklarını, materyal hazırlamanın ve okula götürülmesinin zaman alıcı ve zor olduğunu, okul ya da öğretmenden materyal konusunda yeterli destek görmediklerini ifade etmişlerdir. Aşağıda öğretmen adaylarının neden ağırlıklı olarak etkileşimli tahtaya yer verdikleri, diğer materyallere yer vermedikleri ile ilgili görüşme notlarına yer verilmiştir:

"Etkileşimli tabta, görsel olarak çok zengin olduğu için, çocuğun dikkatini ceketiği için. Öğretmen adayn olarak konuya çok bâkimiyetimiz olmasa bile akull tabta yardmiyla kendimiz̧i rabat bissediyorduk. Etkilessimli tabtay video iそletmek, resim göstermek, etkinlik yaptrmak amacyla kullanyordum. Morpakampiüten etkinlikler yaptrryordum. Etkileşimli tabtada yeterince materyal vardı. Okuma yazma bilmedikleri için diğer materyalleri kullanmadık. Etkilessimli tabta bu konuda yeterliydi." (Ö3)

"Etkilessimli tabtadan video izleterek, kitaptaki etkinlikleri etkilesimli tabtada yaptrryordum. Mürikikler dinletiyordum. Hem ögrenciler hem ben rahatça görebiliyorduk. Dersi daha etkili işlememizi sağhlyor. Öğrenciler kitaptan sılkilyyor; ama etkileşimli tabta daha fazla ilgilerini çekiyor, derse etkin kathlim artiryor. Okulun materyal bakimmndan yetersiz. olusu, materyal hažrlamada zaman sıkintısı yasanmasindan dolay etkileșimli tabta dişndaki diğer materyalleri kullanmadim" (Ö8)

"Etkileşimli tabtayn daha çok kullandim, daha çok önceden temin ettigim videolar ižletmede kullandim. Konuyu somutlaştırmasi, hem görsel, bem işitsel olması, ögrencinin ilgisini gekemesi nedeniyle etkileşimli tabtay tercih ettim. Diğer materyalleri hažrlaması, okula götürmesi zor olduğu için kullanmadim. Hem fakültedeki derslerimin olması, hem de KPSS'ye hazurlanmam nedeniyle zaman problemi yassyorum. Etkilesimli tabtayı kullanmak daha rabat ve daha kolaydi" (Ö9)

Öğretmen adaylarının dersin sonuç bölümünde en çok yer verdiği uygulamanın değerlendirme, en az yer verdiği uygulamanın son özet olduğu tespit edilmiştir. Öğretmen adaylarının dersin sonuç bölümü uygulamalarına pek yer vermeme nedenleri arasında sonuç bölümüne zaman kalmaması, zaman yönetiminde yetersiz olmaları yer almaktadır. Ayrıca adaylar, dersin sonuç bölümünde yapılması gereken ödevlendirmeyi genel olarak günün son dersinde yaptıklarını ifade etmişlerdir. Aşağı̆da öğretmen adaylarının genel olarak dersin sonuç bölümü uygulamalarına yer vermeme nedenleri ile ilgili görüşme notlarına yer verilmiştir:

"Cocuklar neler anladık? diye soruyorum ve cevaplarm alyyordum. Sonra da ben ögrenilenleri özetliyordum. Zaman yetismediği için bazen sonuc uygulamalarm yetistiremiyordum, yapamyordum. Ögrenciler sorular soruyorlard, bunlara cevap vermekten dolay zaman alyordu ve yetismiyordu. Sonuc bölïmü uygulamalarna yer vermemem, zaman yöntemi konusunda deneyimsiz olmamdan da kaynaklanabilir." (Ö4)

"Hayat Bilgisi dersinde sonuc bölïmüne yeterli zaman kalmyyor. Bu durum, zaman yönetiminde yetersiz olmamdan kaynaklanabiliyor. Tabtaya yazdiğımı yazular ögrenciler geç defterlerine geşiriyor. Bu nedenlerle zaman yetmiyor."(Ö2)

\section{Tartışma, Sonuç ve Öneriler}

Sınıf öğretmeni adaylarının öğretmenlik uygulaması kapsamında işledikleri Hayat Bilgisi dersindeki sınıf içi öğretim uygulamalarının ele alındığı bu çalışmada ulaşılan sonuçlar alan yazında yer aldığı gibi giriş, gelişme ve sonuç uygulamaları olarak üç tema altında ele alınmış ve tartışılmıştır. 
Yapılan çalısmada öğretmen adaylarının dersin giriş bölümünde en çok dikkat çekme uygulamalarına yer verdikleri, güdüleme uygulamalarına ise hiç yer vermedikleri belirlenmiştir. Ayrıca öğretmen adaylarının hedeften haberdar etme ve önkoşul öğrenmeleri hatırlatma amacına yönelik öğretim uygulamalarına çok az yer verdikleri sonucuna ulaşııııștır. Yeșil (2001) tarafından yapılan bir araștırmada, öğretmen adaylarının derse giriş yapma ve öğrenci seviyesini tespit etme yolları konusunda eksiklerinin bulunduğu tespit edilmiştir. Öğretmen adaylarının dikkat çekme amacıyla ağırlıklı olarak soru kullandıkları, bunun yanı sıra olay anlattıkları gözlenmiştir. Yapılan görüşmelerde, güdüleme ve hedeften haberdar etmeye pek yer vermemelerinin, nasıl yapacaklarını bilmemeleri, zaman yetersizliği, teori ile uygulamanın birbirinden farklı olması, dikkat çekme aşamasında anlatılan hikâye ya da olayın hedeften haberdar etme ve güdülemeyi sağladığını ve hedefi süreçte öğrencilerinin kendilerinin bulmasının daha faydalı olduğunu düşünmelerinden kaynaklandığını ifade etmişlerdir. Akdağ, Bedir ve Demir (2006, s. 13) tarafindan sosyal bilgiler ve fen bilgisi derslerinde öğretmenlerin dersin giriş etkinliklerini ne düzeyde yerine getirdiklerine ilişkin yapılan bir araştırmada, öğretmenlerin giriş etkinliklerini sık sık ya da orta düzeyde yerine getirdikleri belirlenmiştir. Oral $(2000$, s. 32) tarafindan yapılan bir çalışmada ise öğretmenlerin hedeften haberdar etme uygulamasını düşük düzeyde yaptığı belirlenmiştir. Yine Yeşil (2006, s. 68) tarafindan yapılan bir araştırmada Sosyal Bilgiler öğretmenlerinin, dersin giriş uygulamaları ile ilgili bazı yetersizliklerinin bulunduğu, özellikle de öğrencileri güdüleme, dikkat çekme ve süreçten haberdar etme yeterliklerinde daha büyük eksikler bulunduğu belirlenmiştir.

Öğretmen adaylarının dersin gelişme bölümünde ağırlıklı olarak düz anlatım ve soru cevap yöntemlerini kullandıkları belirlenmiştir. Alan yazında yapılan çalışmaların sonuçları da bu çalışmanın sonucuyla paralellik göstermektedir. (Dursun ve Kuzu, 2008, s. 172; Koç ve Yıldız, 2012, s. 234; Oh ve Kim, 2013, s. 1609; Girmen, Kilıç ve Kaya, 2016, s. 100) Aynı şekilde Lal ve Sarı (2015, s. 648) tarafindan fen bilimleri öğretmenleri üzerinde yapılan bir araştırmada, düz anlatım, soru-cevap yöntemlerinin ve gösteri tekniğinin ağırlıklı olarak kullanıldığ1 görülmüştür. Yeşilyurt ve Semerci (2011, s. 25) tarafindan yapılan araştırmada, öğretmen adaylarının farklı yöntem ve teknikler kullanmadıkları belirlenmiştir. Oysaki Steinbronn ve Merideth (2008, s. 273), öğrencileri daha etkin kılmak için öğretmenlerin anlatım, sorucevap, tartışma yöntemleri dışında farklı yöntem ve teknikleri de uygulamak zorunda olduğunu ifade etmiştir. Anlatım yöntemi fazla hazırlık gerektirmeyen, kullanımı kolay, herhangi bir araç gerece ihtiyaç duymaksızın kullanılabilen bir yöntem olduğu için öğretmen adayları tarafindan daha çok tercih edilmiş olabilir. Abell, Appleton ve Hanuscin'e (2010) göre soru cevap yöntemi öğrencilerin bir konu hakkında detaylı düşünebilmelerini sağlamak, bir konu hakkındaki bilgileri ortaya çıarmak veya konuyu pekiştirmek gibi çeşitli amaçlar için kullanılabilmektedir. Derslerde anlatım ve soru cevap yöntemini kullanmaları, sınıf öğretmeni adaylarının da dile getirdiği gibi fakültede öğrendikleri teorik bilgileri uygulamaya dökemediklerini, özellikle de eğitim fakültesindeki Hayat Bilgisi Öğretimi dersinde öğrendikleri bilgi ve becerileri sınıfta uygulayamadıklarını ortaya koymaktadır. Ayrıca bazı öğretmen adaylarının ifade ettiği gibi, ilkokuldan üniversiteye kadar anlatım ve soru cevap yöntemleriyle yetişmiş olmaları nedeniyle, öğretimin farklı yollarla olabileceğini kabullenmede bile zorlandıkları görülmektedir. Bunlara ek olarak, öğretmen adaylarının fakültedeki dersleri, KPSS sınavına hazırlı yapma gibi nedenlerle zaman problemi yaşamaları, anlatım ve soru cevap yöntemlerinin çok fazla hazırlık gerektirmemesi, stajyer öğretmen olmaları nedeniyle sınıf yönetimi konusunda sorun yaşamalarından dolayı düz anlatım ve soru cevap yöntemlerini tercih ettikleri, diğer yöntemleri kullanamadıkları tespit edilmiştir. Nitekim Aslan ve Sağlam (2018, s. 156) tarafindan yapılan bir çalışmada da öğretmen adaylarının son sınıfta mezuniyet ve KPSS'den yüksek puan alma kaygısı yaşamalarının öğretmenlik uygulamasına gerekli zamanı ve önemi vermelerinin önüne geçtiği belirlenmiştir. Baştürk (2010, s. 63) tarafindan öğretmen adayları üzerinde yapılan bir araştırmada da, öğretmen adaylarının sınıf yönetimi konusunda sorun yaşadıkları belirlenmiştir.

Çağdaş eğitim anlayışında sınıf içinde öğretim materyallerinin kullanılması önemli görülmektedir (Gagné, 1987, s. 3; Gagné, Briggs ve Wager, 1992). Bu çalışmada sınıf öğretmeni adayları tarafından Hayat Bilgisi dersinde en çok kullanılan öğretim teknolojisinin/materyalinin etkileşimli tahta ve ders kitabı olduğu tespit edilmiştir. Sezer (2017, s.27) tarafindan öğretmenlik uygulaması kapsamında sınıf öğretmeni adayları üzerinde yapılan bir çalışmada, en çok yazı tahtasını kullandıkları, daha sonra çalışma kâğıtlarını kullandıkları, bu materyalleri ders kitapları ve etkileşimli tahtanın takip ettiği belirlenmiştir. Ancak etkileşimli tahtanın bulunduğu sınıflarda etkileşimli tahta, yazı tahtası ve ders kitabına karşı önemli bir seçenek haline gelmiştir. Özellikle "morpakampüs”, “okulistik" gibi sanal platformlar öğretmenler için büyük bir kolaylık sağlamaktadır. Sheingold ve Hadley (1990) çalısmalarında öğretmenlerin öğretim sürecinde bilgisayarlardan faydalanmalarının öğrencilere bağımsızlık sağladığını, derse katılımlarını 
arttırdığını ve öğretim sürecinde kolaylık sağladığını tespit etmişlerdir. Warnack, Boykin ve Tung (2008, s. 15) tarafından yapılan araştırmada, derslerde etkileşimli tahta kullanımının öğrencinin motivasyonunu artırdığı; ancak öğrenci performansına etki etmediği sonucu elde edilmiştir. Ayrıca öğretmen adayı tarafindan tasarlanan materyallere pek rastlanmamıştır. Sınıf öğretmeni adayları genel olarak öğretmenlik uygulamasında verdikleri Hayat Bilgisi dersinde etkileşimli tahta dışında kullanabilecekleri yeterli ve uygun materyallere sahip olmadıklarını düşünmektedirler. Bu sonuç, öğretmen adaylarının süreçte kendilerine yardımcı olacak nitelikli materyallere ihtiyaç duyduklarını, fakat bu konuda bir eksikliğin olduğunu göstermektedir. Ayrıca öğretmen adayları farklı materyalleri kullanmamalarını, hazırlık gerektirmesi, zaman yetersizliği, etkileşimli tahtanın yeterince zengin bir içeriği sahip olması gibi nedenlere dayandırmışlardır. Çekirdekçi ve Toptaş (2011, s. 146) tarafından yapılan çalışmada materyal kullanımı sürecinde karşılaşılan sorunlar; dersliklerin fiziki olarak yetersiz oluşu, sınıf mevcutlarının kalabalık oluşu, sınıf kontrolünü sağlanamayışı ve materyal uygulamanın çok fazla zaman alması olarak tespit edilmiştir.

Öğretim sürecinde ipucu, dönüt, düzeltme, pekiştireçlerin kullanılması ve öğrencilerin etkin katılımlarının sağlanması öğretimin niteliğini arttıran uygulamalardır (Bloom, 1976). Öğretmen adaylarının süreçte ipucu ve dönütlere genel olarak yer verdikleri belirlenmiştir. Öğretmen adaylarının ipucu vermede örnekleme, açıklama yapma, soru sorma gibi yollara başvurdukları; dönütü ise özellikle dersin gelişme ve sonuç bölümlerinde kullandıkları tespit edilmiştir. Benzer şekilde, Çevikbaş (2018, s. 116) tarafından lise matematik öğretmenleri üzerinde yapılan bir araştırmada dersin sonuç bölümünde değerlendirme aşamasında kullanıldığı, dersin başlangıcında ise pek fazla dönüte başvurulmadığı tespit edilmiştir. Şahin (2015, s.261) tarafindan üniversite öğrencileri üzerinde yapılan bir çalışmada, öğrenme ve öğretme sürecinde dönüt etkinliklerinin genellikle uygulandığı tespit edilmiştir. Yine Sarıtaş (2011) tarafindan sınıf öğretmenleri üzerinde yapılan bir araştırmada, ders işlemeye ve soru sormaya yönelik dönütleri sıklıkla kullandıkları belirlenmiştir. Öğretmen adaylarının pekiştireçleri ise özellikle soru cevap tekniği ile birlikte kullandığı, pekiştireçlerin öğrencilerin öğrenme isteğini artırdığını söyledikleri tespit edilmiştir. Babayiğit ve Erkuş (2016, s. 576) tarafindan sınıf öğretmenleri üzerinde yapılan bir araştırmada, öğretmenlerin tamamı kullanılan pekiştireçlerin öğrencileri motive ettiğini, olumlu davranışlar kazandırdığını, öğrencilerin derse aktif olarak katılımını sağladığını ve başarıyı artırdığını belirtmişlerdir.

Öğretmen adaylarının dersin sonuç bölümünde en çok yer verdiği uygulamanın değerlendirme, en az yer verdiği uygulamanın son özet olduğu tespit edilmiştir. Öğretmen adaylarının dersin sonuç bölümü uygulamalarına pek yer vermeme nedenleri arasında sonuç bölümüne zaman kalmaması, zaman yönetiminde yetersiz olmaları yer almaktadır. Benzer şekilde, Köksal ve Demirel (2008, s. 200) tarafından öğretmenlik uygulaması kapsamında öğretmen adayları üzerinde yapılan bir araştırmada, öğretmen adaylarının zamanı etkili kullanamadıkları için değerlendirme yapamadıkları belirlenmiştir. Bu durum öğretmen adaylarının tecrübe eksikliği nedeniyle ders süresini etkili kullanamadığını, bunun sonucunda dersin sonuç bölümüne zaman kalmadığını ortaya koymaktadır.

Bu sonuçlar doğrultusunda aşağıdaki önerilerde bulunmak mümkündür:

1. Öğretmen adaylarının dersin giriş bölümünde dikkat çekme dışındaki uygulamalara (güdüleme, hedeften haberdar etme, ön bilgileri hatırlatma) yeterince yer vermedikleri belirlenmiştir. Bu nedenle eğitim fakültelerinde öğretmen adaylarına dersin giriş aşaması etkinlikleri hakkında uygulamalı eğitim verilmelidir.

2. Öğretmen adaylarının öğretim yöntem ve teknikleri ile materyal kullanma konusunda eksiklikleri olduğu düşünüldüğünde, eğitim fakültelerinde öğretim ilke ve yöntemleri, öğretim teknolojileri ve materyal geliştirme vb. derslerde uygulamalı çalışmalara daha çok yer verilmesi önerilebilir.

3. Öğretmen adaylarının zaman yönetimi konusunda sorun yaşadıkları ve bu nedenle dersin sonuç bölümünde gerekli uygulamaları yapamadıkları düşünüldügünde, etkili zaman yönetimi konusunda teorik bilgiye dayalı deneyimlerin kazandırılması gerektiği söylenebilir.

4. Benzer çalısmaların farklı dersler (Türkçe, matematik, fen bilimleri vb.) için de yapılması ve bu derslerdeki uygulamaların derslere göre değişip değişmediğini belirlemek için karşılaştırmalar yapılması önerilebilir.

5. Öğretmen adaylarıyla gerçekleştirilen bu çalışmanın benzerlerinin farklı branşlardaki öğretmen adayları ve ögretmenlerle de gerçekleştirilmesi ve bu çalışmalarda tespit edilen sorunların çözülmesi için çalışmaların yapılması önerilebilir. 


\section{Etik Beyan}

“Sınıf Öğretmeni Adaylarının Hayat Bilgisi Dersindeki Sınıf İçi Öğretim Uygulamaları” başlıklı çalışmanın yazım sürecinde bilimsel, etik ve alıntı kurallarına uyulmuş; toplanan veriler üzerinde herhangi bir tahrifat yapılmamış ve bu çalışma herhangi başka bir akademik yayın ortamına değerlendirme için gönderilmemiştir.

\section{Kaynakça}

Abell, S. K., Appleton, K.. ve Hanuscin, D. L. (2010). Designing and teacbing the elementary science methods course. New York: Taylor \& Francis.

Akdağ, M., Bedir, G. ve Demir, S. (2006). İlköğretim sosyal bilgiler ve fen bilgisi derslerinin öğretiminde öğretmenlerin derse giriş etkinliklerine ilişsin öğrenci görüssleri. Sosyal Bilimler Araştırmalar Dergisi, 2, 1-18

Aktepe, V. ve Yalçınkaya, E. (2016). Hayat bilgisi dersinde değer eğitimi ve uygulama örnekleri. S. Güven ve S. Kaymakçı (Edt.), Hayat bilgisi ögretimi (ss. 134-176) içinde. Ankara: Pegem Akademi Yayıncılık.

Aladağ, S. (2016). Hayat bilgisi: Tanım1, amac1 ve doğası. S. Güven ve S. Kaymakçı (Edt.), Hayat bilgisi ögrretimi (s. 219) içinde. Ankara: Pegem Akademi Yayıncllik.

Aslan, M. (2015). Ë̈̈tim fakiultelerindeki ögretmenlik uygulaması dersinin değerlendirilmesi ve ögretim programmmn hazırlanması (Doktora Tezi). Anadolu Üniversitesi, Eğitim Bilimleri Enstitüsü, Eskişehir.

Aslan, M. ve Sağlam, M. (2018). Öğretmenlik uygulaması dersinin öğretmen adaylarının görüşlerine göre değerlendirilmesi. Hacettepe Üniversitesi Ë̆itim Fakïlltesi Dergisi, 33(1), 144-162.

Babayiğit, Ö. ve Erkuş, B. (2016). Sınıf öğretmenlerinin derslerde kullandıkları pekiştireç ve cezaların etkililiği. Kastamonu Ë̆itim Dergisi, 25(2), 567-580.

Bailey, K. D. (1982). Methods of social research. New York: The Free Press.

Balc1, A. (2005). Sosyal bilimlerde arastruma yöntem, teknik, ve ilkeler. Ankara: Pegem Akademi Yayıncilık.

Baltac1, A. (2017). Nitel veri analizinde Miles-Huberman modeli. Abi Evran Üniversitesi Sosyal Bilimler Enstitisiü Dergisi. $3(1), 1-15$

Baran, M., Yaşar, Ş. ve Maskan, A. (2015). Fizik öğretmen adaylarının öğretmenlik uygulaması dersine yönelik görüşlerinin değerlendirilmesi. Dicle Üniversitesi Ziya Gökalp Eğitim Fakültesi Dergisi, 26, 230-248.

Baştürk, S. (2010). Matematik öğretmen adaylarının uygulama okullarında anlattıkları derslerin niteliği. Marmara Üniversitesi Atatürk. Ë̈itim Fakültesi Ë̆itim Bilimleri Dergisi, 31, 57-68.

Bloom, B. S. (1976). Human characteristics and school learning. McGraw-Hill.

Büyüköztürk, Ş., Killç-Çakmak, E., Akgün, Ö.E., Karadeniz, Ș. ve Demirel, F. (2017). Bilimsel araștrma yöntemleri (23. baskı), Ankara: Pegem Akademi Yayıncilik.

Creswell, J. W. (2007). Qualitative inquiry \& research design: Choosing among five approaches (2. Baski), USA: SAGE Publications.

Çekirdekçi, S. ve Toptaş, V. (2011). Sınıf öğretmenlerinin matematik (4. ve 5. sınıf) dersinde öğretim materyalleri kullanımını engelleyen unsurlarla ilgili görüşleri. Pamukkale Üniversitesi Eğitim Fakültesi Dergisi, 29(1), 137-149.

Çevikbaş, M. (2018). Lise matematik öğretmenlerinin dönüt verme süreçlerinin ve dönüt algılarının incelenmesi. Anadolu Journal of Educational Sciences International, 8(1), 98-125.

Demirel, Ö. (1999). Ögretim ilke ve yöntemleri: Ögretme sanatı (1. Baskı), Ankara:Pegem Akademi Yayıncllı.

Demirkan, Ö. ve Saraçoğlu, G. (2016). Anadolu lisesi öğretmenlerinin derslerde kullandıkları öğretim yöntem ve tekniklerine ilişkin görüşleri. The Journal of International Lingual, Social And Educational Sciences, 2(1), 1-11.

Dursun, Ö. Ö. ve Kuzu, A. (2008). Öğretmenlik uygulaması dersinde yaşanan sorunlara yönelik ögretmen adayı ve öğretim elemanı görüşleri. Selçuk Üniversitesi Abmet Keleşoğlu Ë̆itim Fakültesi Dergisi, 25, 159-178.

Gagné, R. M. (1987). (Ed.). Introduction, instructional tecbnology: Foundations. New Jersey: Lawrence Erlbaum Associates.

Gagné, R. M., Briggs, L. ve Wager, W. W. (1992). Principles of instructional design. New York: Holt, Rinehart and Winston, Inc.

Girmen, P., Kılıç, Z. ve Kaya, M.F. (2016). Öğretmenlik uygulaması dersi kapsamında sınıf öğretmeni adaylarının uygulama örneklerinin incelenmesi. Eg̈itim ve İnsani Bilimler Dergisi: Teori ve Uygulama. 7(13), 89-108.

Glesne, C. (2014). Nitel araştırmaya giriş. A. Ersoy ve P. Yalçınoğlu (Çev. Edt.). Ankara: Anı Yayıncılık.

Gürbüztürk, O. ve Genç, S. Z., (2004). Öğretmen adaylarının öğretmenlik mesleğine ilişkin görüşleri. İnönü Üniversitesi Ë̆itim Fakültesi Dergisi, 5(7), 1-11.

Harris, N. H. ve Sass, T. M. (2010). Teacher training, teacher quality and student achievement. Journal of Public Economics, 95(7-8), 798-812. doi: 10.1016/j.jpubeco.2010.11.009.

Haydn, T. A. ve Barton, R. (2007). Common needs and different agendas: how trainee teachers make progress in their ability to use ICT in subject teaching. Some Lessons From the UK. Computers \& Education, 49(4), 10181036. doi: $10.1016 /$ j.compedu.2005.12.006

Jacob, B. A. ve Lefgren, L. (2004). The impact of teacher training on student achievement: Quasi-experimental evidence from school reform efforts in chicago. Journal of Human Resources, 39(1), 50-79. doi: 10.3386/w8916.

Koç, C. ve Yıldız, H. (2012). Öğretmenlik uygulamasının yansıtıcıları: Günlükler. Eğitim ve Bilim, 37(164), 223-236. 
Köksal, N. ve Demirel, Ö. (2008). Yansıtıcı düşünmenin öğretmen adaylarının öğretmenlik uygulamalarına katkıları. Hacettepe Üniversitesi Eğitim Fakültesi Dergisi, 34, 189-203.

Lal, İ. ve Sarı. M. (2015). Mesleki kıdemleri farklı fen bilimleri öğretmenlerinin öğrenme öğretme sürecini düzenleme biçimlerinin karşılaştırılması. Pegem Eğitim ve Öğretim Dergisi, 5(5), 637-666, http:/ /dx.doi.org/10.14527/pegegog.2015.035.

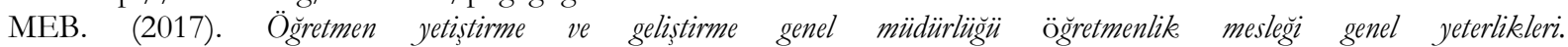
http://oygm.meb.gov.tr/www/ogretmenlik-meslegi-genel-yeterlikleri /icerik/39 adresinden 18.11.2018 tarihinde edinilmiştir.

Merriam, S. B. (2013). Nitel araștırma desen ve uygulama için bir rehber. Selahattin Turan (Çev. Edt.). Ankara: Nobel Yayınları.

Miles, M, B. ve Huberman, A. M. (1994). Qualitative data analysis: An expanded sourcebook. Thousand Oaks, CA: Sage.

Moore, K. D. (2000). Öğretim becerileri (Ed. Ersin Altıntaş) (Çev. Nizamettin Kaya). Ankara: Nobel Yayınevi.

Neuman, L. W. (2014). Social research methods: Qualitative and quantitative approaches. Essex: Pearson Education Limited.

Neuman, W. L. ve Robson, K. (2014). Basics of social research. Toronto: Pearson Canada.

Oh, P. S. ve Kim, K. S. (2013). Pedagogical transformations of science content knowledge in korean elementary classrooms. International Journal of Science Education, 35(9), 1590-1624.

Oral, B. (2000). Öğretmen adaylarının ortaöğretimde çalışan öğretmenlerin öğretim davranışlarına ilişkin algıları. Eğitim ve Bilim, 25(115), 28-34.

Paker, T. (2008). Öğretmenlik uygulamasında öğretmen adaylarının uygulama öğretmeni ve uygulama öğretim elemanının yönlendirmesiyle ilgili karşılaştıkları sorunlar. Pamukkale Üniversitesi Eŭitim Fakültesi Dergisi, 1(23), 132-139.

Sabancı, A. ve Şahin, A. (2005). Öğretmenin etkinlik odaklı hayat bilgisi öğretiminde sınıf yönetimi değişkenleri açısından değerlendirilmesi: Bilen öğretmenden bulduran öğretmene doğru. Eğitimde Yansımalar: VIII. Yeni Illkögretim Programlarm Değerlendirme Sempozyumu, Kayseri Erciyes Üniversitesi. Ankara: Sim Matbaas1.

Sağlam, H. İ. (2015). Toplum, birey ve doğaya bütüncül bakış: Hayat bilgisi. M. Gültekin (Edt.) Hayat bilgisi ögretimi içinde (ss. 1-15). İstanbul: Nobel Yayıncılık.

Sheingold, K., ve Hadley, M. (1990). Accomplished teachers: Integrating computers into classroom practice. New York: Bank Street College, Center for Technology in Education.

Shantz, D. (2005). Öğretmen eğitiminde yenilikçi bir yaklaşım mı yoksa geleneksel bir anlayış mı? (Çev. E. Gökçe ve C. Demirhan). Ankara Üniversitesi Eğitim Bilimleri Fakültesi Dergisi, 38(2), 187-195. doi: 10.1501 /Egifak_0000000115.

Sarıçoban, A. (2008). Okul deneyimi ve öğretmenlik uygulaması derslerine ilişkin uygulama öğretmenleri ve öğretmen adaylarının görüşleri. Gaz̨i Üniversitesi Gaz̨i Ë̈itim Fakültesi Dergisi, 28(3), 31-55.

Sarıtaş, M. (2011). Sınıf öğretmenlerinin dönüt ve düzeltme davranışlarını kullanma düzeyleri. I. Uluslararası Ĕ̈itim Programlar ve Ögretim Kongresi, 05-08 Ekim 2011, Eskişehir.

Sezer, G.O. (2017). Öğretmenlik uygulaması dersini alan sınıf öğretmeni adaylarının sınıfta kullandıkları materyal tercihlerinin incelenmesi. Academy Journal of Educational Sciences, 1(1), 23-33.

Sönmez, V. (2010). Program gelistirmede ögretmen elkitabı (16. baskı), Ankara: Anı Yayınc1lik.

Steinbronn, P. E. ve Merideth, E. M. (2008). Perceived utility of methods and instructional strategies used in online and face-to-face teaching environments. Innovative High Education, 32, 265-278

Şahin, M. (2015). Öğrenme ve öğretme sürecinde uygulanan dönüt etkinliği ile ilgili öğretmen adaylarının görüşlerinin incelenmesi. Abant İzet Baysal Üniversitesi Ë̆itim Fakültesi Dergisi, 15(USBES Özel Sayıs1 I), 247-264.

Şişman, M. ve Acat, M. B. (2003). Öğretmenlik uygulaması çalışmalarının öğretmenlik mesleğinin algılanmasındaki etkisi. Furat Üniversitesi Sosyal Bilimler Dergisi, 13(1), 235- 250.

Taşdemir, M. (2000). Eğitimde planlama ve değerlendirme. Ankara: Ocak Yayınları.

Türnüklü, A. (2000). Eğitimbilim araştırmalarında etkin kullanılabilecek nitel bir araştırma tekniği: Görüşme. Kuram ve Uygulamada Ë̆itim Yönetimi, 24, 543-559.

Warnock, S. H., Boykin, N. J. ve Tung, W. C. (2011). Assessment of the impact of smart board technology system use on student learning, satisfaction, and performance. Journal of Research in Education, 21(1), 1-20.

Yeşil, R. (2006). Sosyal bilgiler öğretmenlerinin sınıf içi öğretim yeterlikleri (Kırşehir örneği). Abi Evran Üniversitesi Kirşehir Eğitim Fakülttesi Dergisi, 7(2), 61-78.

Yeşil, R. ve Yeşil, S. (2007). Öğretim ilke ve yöntemleri. Kırşehir: Öğrenci Kitabevi Yayınları.

Yeşil, S. (2001). Hayat ve sosyal bilgiler ögretimi becerilerine eğitim fakültesi son sinf ögrrencilerinin sabiplik düzeyi (Yüksek Lisans Tezi). Van Yüzüncü Yıl Üniversitesi, Sosyal Bilimler Enstitüsü, Van.

Yeşilyurt, E. ve Semerci, Ç. (2011). Uygulama öğretmenlerinin öğretmenlik uygulaması sürecinde karşılaştıkları sorunlar ve çözüm önerileri. Akademik Bakış Dergisi, 27, 1-23.

Yıldırım, A. ve Şimşek, H. (2013). Sosyal bilimlerde nitel araştırma yöntemleri. Ankara: Seçkin Yayıncılık.

Yıldırım, A. (2013). Türkiye'de öğretmen eğitimi araştırmaları: Yönelimler, sorunlar ve öncelikli alanlar. Eğgitim ve Bilim. 38(169), 175-191.

\section{EXTENDED ABSTRACT}


Nowadays, it is widely accepted that there is a close relationship between the quality of the teacher and the quality of education. In order for the teachers to be successful in education, they need to undergo a qualified training before starting the profession. For this purpose, student teachers in the faculties of education should be subjected to a theoretical and practical training in order to be sufficient in the introduction, development, conclusion and evaluation stages of the teaching process. The teaching practice course, which is given in the last class of the faculty, has an important place in the pre-service teachers' practices in their education. Student teachers process various courses in the practice process and they can put their theoretical knowledge into practice in these courses. However, the degree to which this function of teaching practice occurs can be expressed as a problem. For this reason, which teaching practices and how and why teachers are included in the courses should be determined. The purpose of this study is to examine the in-class teaching practices of the student teachers of 'Life Science' course. It is thought that determining the teaching practices of the Life Science course which has an important function in primary school will contribute to the pre-service education of the student teachers. Moreover, considering the lack of studies in which student teachers' classroom teaching practices in various courses are considered, this study will contribute to the related literature.

The study was conducted according to the case study pattern of qualitative research designs. The data of the study were collected from 11 student teachers who are studying in Van Yüzüncü Y1l University Faculty of Education and continue their teaching practices. As data collection tool observation form and semi-structured interview form developed by the researchers were used. In addition, the working group consisted of six male and five female class teachers in order to eliminate the effects of gender factors. The data, collected through observation and interview during the research process were analyzed by using content analysis one of qualitative data analysis techniques and descriptive analysis techniques. Content analysis was used to determine the classroom teaching practices of the student teachers and descriptive analysis was used to determine how and why they performed these analyzes. To ensure the validity of the study, the researcher has disseminated the observation period. In addition, analyses were subjected to consistency examination by a third expert experienced in the subject researched and the content of the themes were confirmed. In addition, the internal validity of the study was tried to be increased by the participant confirmation. The study data were encoded independently by two researchers and the compatibility between the encoders was calculated. As a result of the calculation, the compliance rate was determined as $91 \%$. Over $70 \%$ indicates that the findings and results are reliable.

In the study, it was concluded that the pre-service teachers gave the most attention-taking practices in the introductory section of the course, they did not give any place to the motivation practices, and they gave very little place to the instructional applications for the purpose of informing the target and remembering the prerequisite learning. It has been observed that student teachers mainly use questions to draw attention, as well as telling events. It was determined that the student teachers mainly use lecture and question-answer methods in the development section of the course. It was determined that pre-service teachers preferred the lecture and question-answer methods because have time problems due to the intensity of their courses in the faculty, the time problems due to the preparation of state selection exam, lecture and question-answer methods do not require much preparation and because they also stated that as they are student teachers they have class management problems. It has been determined that the most widely used instructional technology/material in life science course is interactive board and textbook. It was determined that student teachers generally include clues and feedback in the process. It was determined that the student teachers applied to the methods such as sampling, clarification and asking questions in order to give clues, and that they used feedbacks in the development and conclusion parts of the course. It is determined that the student teachers use reinforcements together with the question and answer technique and the reinforcements increase the students' desire to learn. It has been determined that student teachers give much place to evaluation but don't perform the last summarize in the final part of the course.

For this reason, student teachers in the faculty should be given practical training about the course introduction stage activities. Considering the shortcomings of the student teachers in using teaching methods and techniques and materials, practical studies can be performed in the courses. Considering the fact that student teachers experience problems in time management and therefore cannot make the necessary applications in the conclusion part of the course, it can be said that the experience based on theoretical knowledge should be gained in effective time management. 